\title{
SATELLITE PERSPECTIVES ON HIGHLAND - LOWLAND HUMAN INTERACTION IN ANCIENT SYRIA
}

\author{
M. Lönnqvist, M. Törmä, K. Lönnqvist, M. Nuñez \\ Contact person: Minna Lönnqvist, minna.lonnqvist@aalto.fi
}

KEY WORDS: Landscape, Archaeology, Remote Sensing, Modelling, Vision, Environment, Geomorphology

\begin{abstract}
:
Nowadays we can travel by GoogleEarth 3D to Syria (http://www.worldcountries.info/GoogleEarth/GoogleEarth-Syria.php) and zoom in on the desert landscape of the mountainous region of Jebel Bishri between the Euphrates river and the Syrian Desert. This is the area, where the Finnish archaeological survey and mapping project SYGIS worked in 2000-2010 studying the relationship of humans with their environment from ancient times to the present. What kind of landscape views and visions did the ancients have and how did they utilize them? The present paper focuses on seeking answers for these questions by combining satellite data sources, such as imagery and radar data, with location information of archaeological remains collected on the ground. Landsat as well as QuickBird imagery have been fused with SRTM mission and ASTER DEM data in creating 3D landscape models and fly-over simulations. The oasis of El Kowm on the western piedmont of the mountain seems to have served as a base camp for early huntergatherers and pastoral nomads dwelling seasonally in the region of Jebel Bishri. According to the archaeological finds, the interaction between the lowland and the mountain people already started during the Palaeolithic era but was continued by pastoral nomads of the region from the Neolithic period onwards. The Upper Palaeolithic period meant a clear change in cognitive thinking and obviously in understanding the properties of landscape, visibility and perceiving sceneries in 3D. Mobility of hunter-gatherers and pastoral nomads is based on subsistence economy, but mobility also enhances visions and prospects of phenomena appearing in the horizon.
\end{abstract}

\section{INTRODUCTION}

\subsection{Approaching Jebel Bishri in Syria from a 3D Perspective}

According to the structuralist F. Braudel (1972), in the Mediterranean landscape mountains come first. The mountains resist the pace of history, but the lowland and highland people have always held contact with each other. After Braudel P. Horden and N. Purcell (2000) have reinterpreted the Mediterranean landscape as consisting of micro-regions comprising variety in different scales.

Mountains form relief patters for the surface of earth; their geomorphology is ultimately the result of tectonic movements causing uplifts and subsidence, while climate, humans, flora and fauna function as agents in erosion and sedimentation (Rendell, 2000, Butzer, 1982,). Mountains are areas which humans have early on used for prospecting and studying visibility over far away areas. Their forms evoke memory and myths in human minds (cf. Clack, 2007), but they also provide prospects and expectations for what appears from the horizon. For early hunters such prospects were economically important.

Nowadays we can travel by GoogleEarth 3D to the mountainous region of Jebel Bishri (Fig. 1.) in Central Syria (http://www.worldcountries.info/GoogleEarth/GoogleEarth-

Syria.php) and zoom in on the desert - steppe landscape in the Palmyride mountain belt. Jebel Bishri is the area where the Finnish archaeological survey and mapping project SYGIS worked in 2000-2010 studying the relationship of humans with their environment from the past to the present by using satellite data sources, Geographic Information Systems (GIS, see Lönnqvist and Stefanakis, 2009) and archaeological field work.

The human mind and the ability to perceive by the eye and brain the surrounding landscape are central issues in studying ancient landscapes and the development of human understanding of the $3 \mathrm{D}$ qualities of surroundings. The perception has an impact on exploitation and modification of the environment. In this paper our aim is to reconstruct, present and study present landscapes in $3 \mathrm{D}$ from the Jebel Bishri region in order to understand what kind of landscape views and visions the ancients had and how they perceived and utilized them. The present paper tries to seek answers for these questions by 1) using satellite data sources in 3D landscape reconstructions, 2) consulting related archaeological data and 3) utilizing landscape theory. Cultures change landscapes and in a reciprocal way are affected by them in their own evolution (cf. Nassauer, 1995). The reconstruction of past landscapes initially concerns geomorphology (Butzer, 1982) after which possible flora and fauna are studied.

In our further studies and analyses of landscapes of Jebel Bishri, the theories and methodologies of M. Llobera (2001) concerning ancient landscape perception by using GIS have become relevant. In the case of Jebel Bishri the understanding of such features as topographic prominence, which Llobera has also discussed, has become important in the mountain landscape. The mountain edges, peaks and generally undulating character of topography provide an arena for such studies.

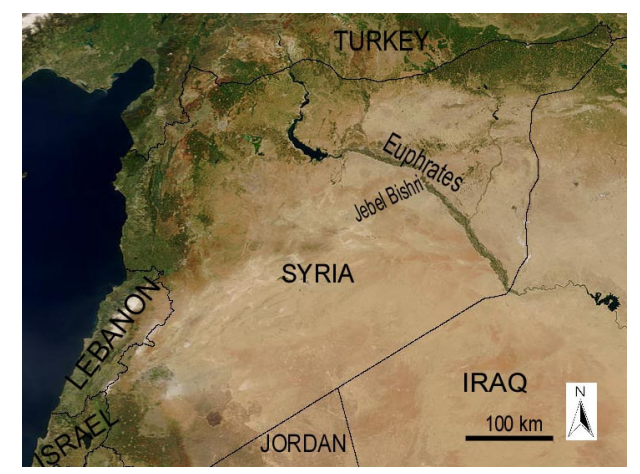

Figure 1. The location of Jebel Bishri, a mountain in Central Syria along the Euphrates, on a satellite image. Mapping by M. Lönnqvist 2009. 
By illustrating the landscapes of the region in $3 \mathrm{D}$ one is able to display and study topographical features between the highland and lowland areas as well as human inter-action between those areas; the 3D provides a multi-dimensional aspect to study the landscape context of cultural development. The two areas on the ground developed in this dimension throughout the past, and now the modern technology provides us with tools to capture and experience different kinds of dynamic landscape visions for experimental use.

The area of Jebel Bishri has had a continuous human occupation for hundreds of thousands of years, and mobile subsistence economies have played a central role among various groups. The archaeological data tells us about the types of human groups, their subsistence economy and cultures which have lived in this marginal habitat. (Lönnqvist et al., 2011). Early people in the Mediterranean and the Near East must have had "mental maps" of their landscape surroundings, which affected the treatment of the environment. Therefore we need both geosciences as well as archaeology for approaching and understanding landscape development. (Barker and Bintliff, 1999).

Archaeology is the only discipline that can study the interaction of humans with their environment from a long-term perspective. The environmental and landscape reconstructions illustrate and add to the knowledge of archaeology and elucidate possible conditions which prevailed in the area that has been desert and steppe for millennia. The climate change is not solely a modern phenomenon but has been a reoccurring state of equilibrium in the surroundings of early humans as well. A major change happened when the previous ice age ended. It meant changes in human exploitation of the nature. During the previous Pleistocene era humans were only living by hunting and gathering. The reason for continuing mobility in the region of Jebel Bishri during the following Holocene period has been the aridity, which does not support continuous agriculture without irrigation. (Cauvin, 2000). Initial agriculture in the region, however, seems to have enjoyed the benefit of river fans, natural flooding and oasis environment. Beside the Euphrates sites such as Abu Hureyra and Mureybet (Moore et al., 2000) first steps towards agriculture were taken in the oases surrounded by mountains, such as Jericho, El Kowm and Aswad (the Damascus region ) in the Levant. (Cauvin, 2000).

\section{GEOMORPHOLOGY AND ITS 3D ILLUSTRATION}

\subsection{Reconstructing Environment and Landscape Views in 3D}

The area of the Palmyrides is a northern continuation of the larger Arabian platform in geological terms. Jebel Bishri, which belongs to the Palmyrides, is a block mountain that reaches ca. $867 \mathrm{~m}$ above sea level (Wirth, 1971) and follows the Euphrates river. Its table-like form with sharp edges in the skyline has been encountered and wondered by ancient and modern people living in the region. The mountain which belongs to arid zones basically consist of gypsum, sandstone, lime stone and marble beside basalt. Playas, salt plains, are common on the western piedmont area. (see e.g., Besançon et al., 1981; Lönnqvist et al, 2011).

In the steppic and desert landscape of the mountain some striking elements were identified on the ground and from satellite imagery. Volcanic activity has created basaltic areas and natural asphalt emerging in the region which also contains oil resources. At the northern edge there protrudes the basaltic peninsula of Halabiya (Fig. 2.), and in the central district of the mountain rises a basaltic formation known as Jebel Hemet elQuebiba (Lönnqvist et al., 2011).

In the Finnish project landscape models have been created using Landsat satellite image data (MSS: $80 \mathrm{~m}$ in resolution, TM: 30 $\mathrm{m}$ in resolution and ETM: $30 \mathrm{~m}$ in resolution, the panchromatic channel resolution being $15 \mathrm{~m})$, QuickBird ( $0.6 \mathrm{~m}$ in resolution) and SRTM mission data (90 m and $30 \mathrm{~m}$ in resolution) as well as ASTER image data (30 $\mathrm{m}$ in resolution, see Fig. 2.), the latter sources providing radar data for 3D landscape scenes. In addition, available topographical maps have been utilized. (Lönnqvist et al. 2011).

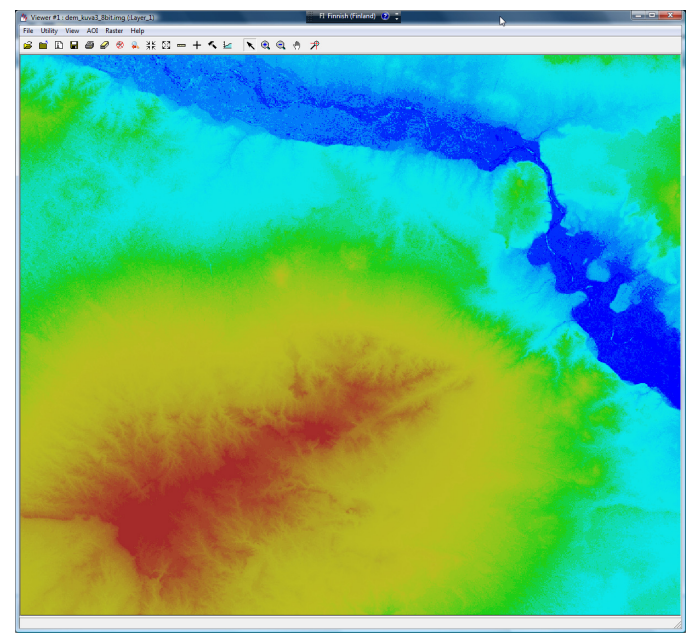

Figure 2. Jebel Bishri, the Euphrates trough and the oval volcanic and basaltic outcrop known as the peninsula of Halabiya visible on ASTER images. Compiled and coloured by M. Törmä 2012.

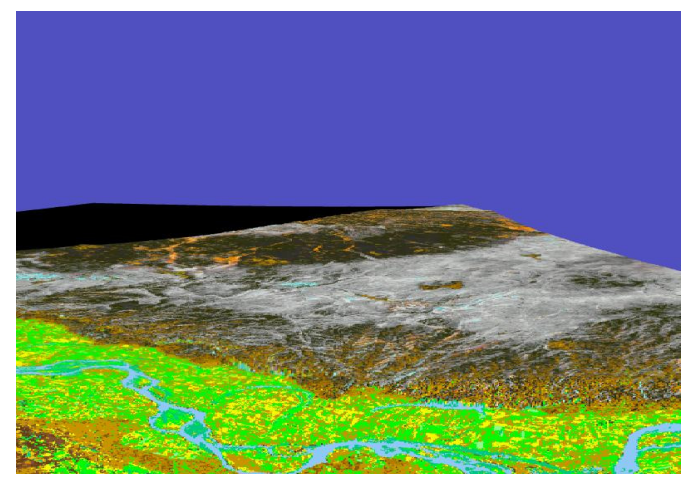

Figure 3. A3D landscape reconstruction of Jebel Bishri and the Euphrates valley seen from $\mathrm{N}$. The image is displaying the geomorphology, such as caused by the run-off mechanism leading waters coming from the mountain into the valley. Constructed by M. Törmä 2003.

The SRTM mission data has been used by our project since the year 2003 for building up a model of the Euphrates channel following the mountain edge and by approaching the mountain from different geographical directions. The Landsat data has been used as a reference source, and its data has also been fused with SRTM data (Fig. 3.). 3D models and fly-over simulations have been produced with ERDAS Imagine (see video-clips: www.helsinki.fi/hum/arla/sygis). A cross-section of the river 
channel was produced by using ASTER DEM data in order to study the ancient river channel changes, terraces and banks (see Lönnqvist et al., 2007). In addition, the project has produced several satellite image analyses which reveal the geomorphology. Besides identifying the palaeolake depression of Nadra from Landsat-7 ETM image by cluster analysis and studies on the ground, the project has analysed the movement of the extending sand cover and explosive desertification in the area of Jebel Bishri (Lönnqvist et al., 2011).

\section{THE INTERRELATIONS BETWEEN THE WESTERN PLAINS AND THE MOUNTAIN}

\subsection{The Oasis of El Kowm as a Base Camp}

The oasis of El Kowm (Fig. 4.) on the western piedmont of the mountain lies ca. $450 \mathrm{~m}$ above sea level and is situated in a 20 $\mathrm{km}$ wide mountain pass. The basin is a little over $400 \mathrm{~m}$ lower from the peak of Jebel Bishri. It obviously served also as a base camp for the early hunter-gatherers, who were foraging and hunting in the region of Jebel Bishri. Long-term site formation processes took place in the oasis. In this arid landscape early on dozens of springs have attracted animals to the oasis, and human occupation in the area probably covers ca. 1 million years (Le Tensorer et al., 2007). Dozens of prehistoric sites (see Fig. 5.) have been traced in the region (see e.g., Besançon et al., 1981).

At the western edge of Jebel Bishri a semicircular escarpment is called Tar al-Sbai (Fig. 4.) according to the Bedouin tribal border of the Sba'a tribe. Tar al-Sbai is facing the El Kowm oasis that is situated on the western plains beneath. The 3D image of the El Kowm and Tar al-Sbai area can be captured and flown over by GoogleEarth 3D at 35'11'05,66' $\mathrm{N}$, $38^{\circ} 50^{\prime} 11,80^{\prime \prime}$ E. The relationship of these two areas becomes more visible.

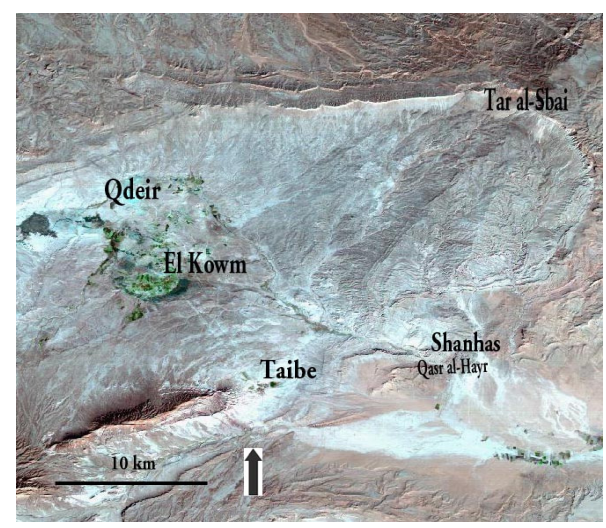

Figure 4. The oasis of El Kowm and Tar al Sbai at the edge of Jebel Bishri. Mapping on Landsat-7 ETM image by $M$. Lönnqvist 2001.

The area of Tar al-Sbai comprises several abris, rock-shelters, of early hunter-gatherers that obviously frequented from the El Kowm basin up to the mountain proper. According to the finds, the visits to the area already started during the Palaeolithic era, but the greater utilization of the district is identified in the lithic workshops associated with abris dating from the Upper Palaeolithic and Epipalaeolithic eras. (Lönnqvist and Törmä, 2003; Lönnqvist et al., 2011). The visits extended as far as the palaeolake of Nadra in the central area of the mountain during the Middle Palaeolithic period. During the Epipalaeolithic the emergence of the Natufian culture along the improvements in climatic conditions and population growth ca. 13, 000 B.P. apparently developed in greater control of resources which led to territorialism (Bar-Yosef, 1998).

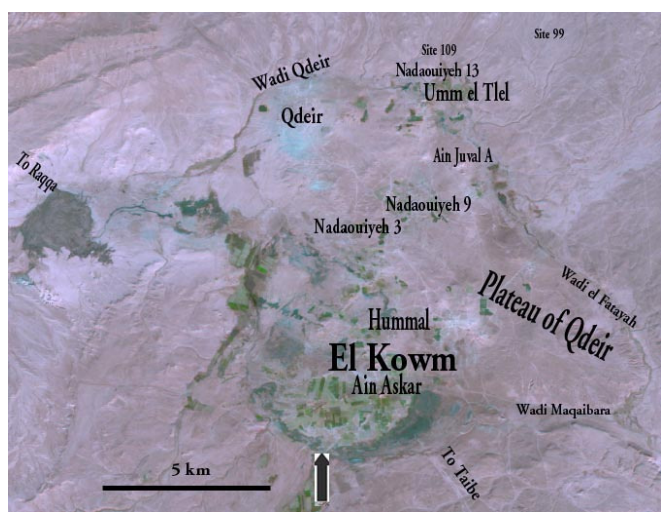

Figure 5. Prehistoric sites in the El Kowm basin displayed on a Landsat-7 ETM image. Mapping on Landsat-7 ETM image by M. Lönnqvist 2009, basing information on Besançon et al., 1981.

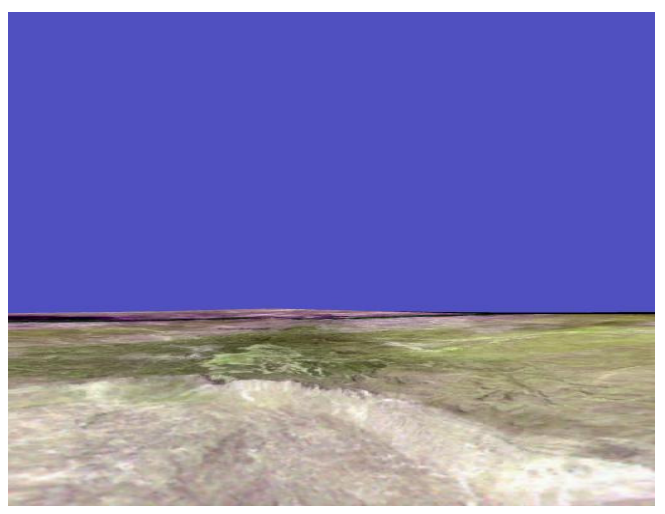

Figure 6. A computerized 3D landscape scene towards Tar alSbai from SW from the mosaic of Landsat-4 MSS images. Note the visibility to the Euphrates valley behind. Constructed by M. Törmä 2006.

Because of their height and good visibility, the sites at Tar alSbai may simply be interpreted as lookout-points or observation-points at the mountain edges to control the surrounding steppe and desert plateau. From the edge, the approaching visitors could be seen and information could be spread. Lookout-points or observation-points are usually such that they provide extensions of the horizon for the field of vision in several directions. There are speculations concerning the things that are beyond the horizon, and in the human minds an extension of the horizon brings satisfaction (Appleton, 1975). In 2001 we already carried out computer-aided vision analyses from the mountain edge towards the western desert plateau using Russian topographic maps and Image Drape (Fig. 7., Lönnqvist et al., 2001 in press). Later on a vision analysis was carried out over the western plain by fusing Landsat image data with ASTER DEM data (Fig. 8.).

Our hypothesis is that visions and vistas were not only enjoyed because of their impressive values at the edge of the mountain but also due to practical considerations in connection with gazelle hunting and pastoral grazing. (Lönnqvist and Törmä, 2003; Lönnqvist et al., 2011). 


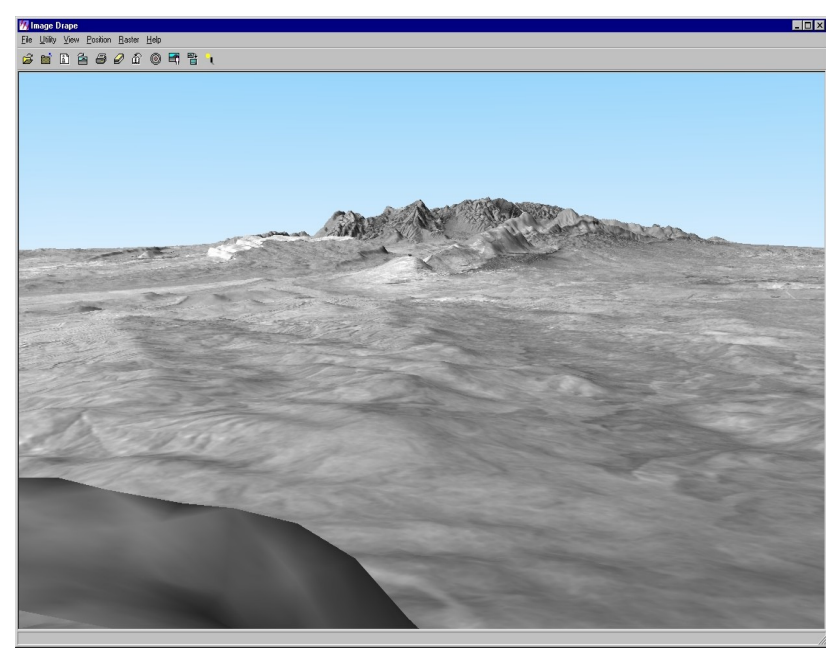

Figure 7. A perspective view over the western piedmont seen from Tar al-Sbai built from Russian topographic map data using Image Drape. Constructed by A. Vuorela 2001, 2002.

\subsection{From Gazelle Killing to Pastoral Nomadism}

A series of the western piedmont oases between the two mountain ranges belonging to the Palmyrides formed the socalled Levantine corridor identified by O. Bar-Yosef (1998). The corridor did not only become an arena for gazelle hunting and the development of pastoral nomadism but also an experimental field for human sedentarization. The corridor has served as a seasonal route of gazelles which moved from the Arabian peninsula towards the oasis of El Kowm and further to the ancient village of Abu Huryera on the Euphrates (Legge and Rowley-Conwy, 1987, Moore et al., 2000). The flocks apparently continued further up to Göbekli Tepe, where a Neolithic sanctuary for hunters existed, in Turkey.

The so-called kites, large V-shaped gazelle traps built of stone rows, were located in the corridor. Similar constructions have been identified in numbers in basaltic areas of the Black Desert of Jordan and in the Hemma plateau of Syria, where rock art of the formations have also been recovered (Van Berg et al., 2004). The sites, such as Abu Hureyra, based their subsistence economy at an early stage on gazelle killing. Gazelle was the main source of protein of these ancient people, and A.J. Legge and P.A. Rowley Conwy (1987) have suggested that the shortage of the gazelle meat and thus protein stimulated people towards animal husbandry.

The escarpment of Tar al-Sbai may represent an area for seasonal hunting grounds used by the inhabitants of base camps situating in the El Kowm basin nearer to perennial water sources. Comparable archaeological finds from both areas point to the related human groups. This relation between Tar al-Sbai and El Kowm would therefore indicate to the first steps towards the highland-lowland interaction, "transhumance" in D.O. Henry's line (1989) ${ }^{1}$. This habitat tracking may have already started among Palaeolithic hunter-gatherers continuing among

\footnotetext{
${ }^{1}$ Transhumance is a term primarily applied to pastoral societies and their seasonal movements from base villages in lowlands to grazing lands in highlands, but, for example, D.O. Henry (1989) uses the term to illustrate seasonal movement of hunter-gatherers over different environments/habitats already in the Middle Palaeolithic times (Henry 1995, 373) .
}

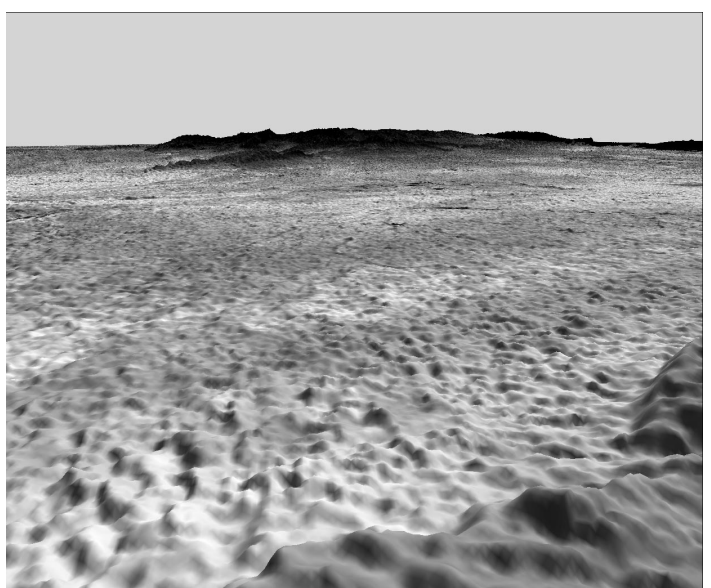

Figure 8. A perspective view over the western piedmont built from Landsat-5 TM image using Image Drape with Erdas Imagine and ASTER DEM. Constructed by M. Törmä 2012.

Epipalaeolithic foragers and later among pastoralists in the arid areas of the Levant. In stone tool finds lance and arrow heads are represented on the piedmont showing the activity of hunting in the region. The recovered small tools such as scrapers at Tar al-Sbai indicate that butchering and leather processing were especially active at the abri sites, and a number of hunter's blinds prove considerable hunting activities at some point of time. Interestingly the blinds were set at the slopes and edge of the mountain where the flocks of animals such as gazelles traversed (Lönnqvist et al., 2011).

\subsection{Pastoral Transhumants, Preferred Grazing and Burial Grounds}

As previously mentioned, the mountain was the arena of hunters and foragers during the Palaeolithic as well as Epipalaeolithic period, but later on it served as grazing grounds for pastoralists: the interest of both groups was in acquiring meat. Actually we may find the echo of the word "meat" in the ancient Akkadian name of Jebel Bishri which was called Bašar. The mountain could therefore have served as a "meat warehouse" for mobile people (Lönnqvist et al., 2011).

The study of pastoral landscapes needs to take into account both physical as well as managerial dimensions of the landscape. Patoralists play an important role in shaping the landscape (Ruiz et al., 1983). In the region of Jebel Bishri the highland-lowland interaction is close to the Bedouin life today which is comparable to that of the ancient pastoralists. Ancient pastoral structures, such as corrals i.e. animal pens, in the central area of the mountain form evidence of preferred landscapes and indicate to the existence of transhumance. The El Kowm basin has also provided evidence for the earliest steps towards pastoral nomadism during the Pre-Pottery Neolithic B (PPNB) period (Cauvin, 2000).

We have studied the density of ancient corrals, animal pens, on the mountain and their site catchment areas by using GIS. The studies and analyses illustrate the radius of the movements of pastoralists during their grazing around these pens. The pens appeared to be strikingly numerous in the highest areas of the mountain where also satellite image cluster analyses revealed the greenest surroundings for grazing. Interestingly not many permanent dwelling structures were found in association with the pens which indicates to the possible existence of huts or tents - and thus not permanent housing. Therefore, the grazing 
could have followed the modern type of transhumance in which winters are spent in lower grounds in the river valley or in the surrounding plains. (Lönnqvist et al., 2011).
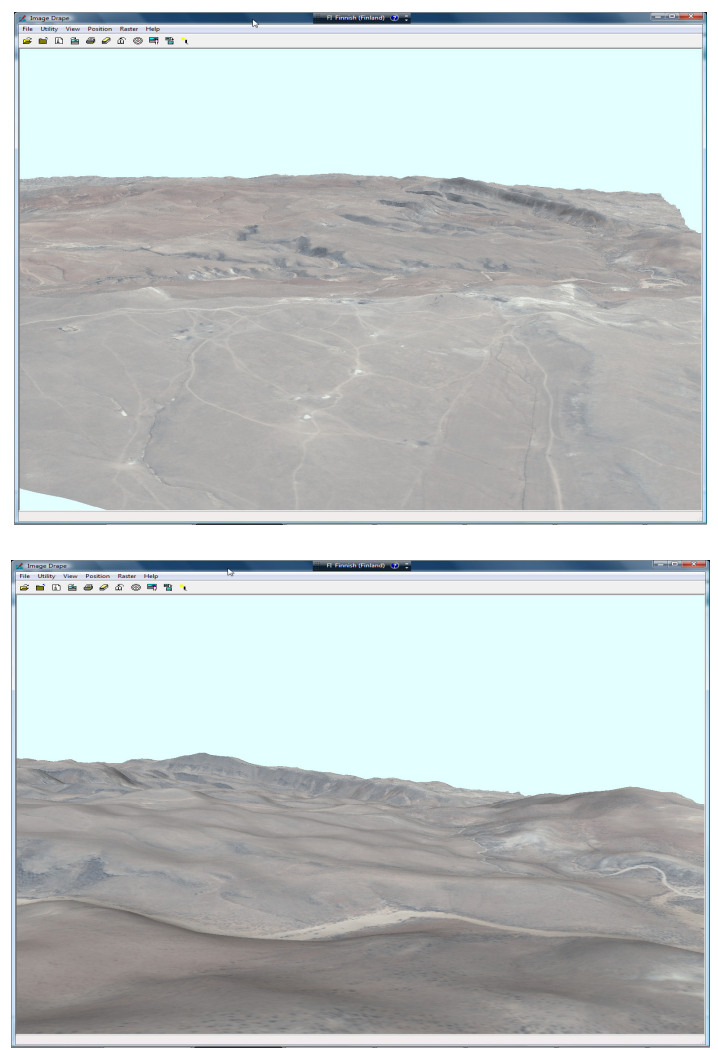

Figures 9. and 10. 3D landscape models from the central area of Jebel Bishri constructed by fusing QuickBird imagery with ASTER image. Constructed by M. Törmä 2012.

The pattern of undulating desert-steppe landscape with hills, plateaus, valleys and ravines known as wadis in the central areas of Jebel Bishri is most photo-realistically visible in 3D landscape models produced by fusing high resolution satellite image data such as QuickBird $(0.6 \mathrm{~m}$ in resolution) with ASTER DEM data (Figs. 9.-10.). The wavy patterns, repeated forms, in the landscape are discernable; they provide the moonvalley-like aesthetics in the central region (cf. Bell, 1999). There is no flora to hinder the visibility. The view over these areas was not obviously as bare and desolate in prehistory when the region may have looked more like a savannah.

The archaeological finds indicate that since the Neolithic period pastoralism was the main mode of subsistence economy of the region, and agricultural endeavours were very limited and seasonal, mainly in wadis. (Lönnqvist et al., 2011). Beside corrals the pastoral landscape of Jebel Bishri is punctuated by cairn/tumulus type of burials on hillocks. During the Chalcolithic and Bronze Age the mountain had become the realm of animals and burial grounds for ancestors. Also special signposts constructed of piles of stones were encountered on higher grounds to guide the pastoralists in the landscape. (Lönnqvist et al. 2011).

\subsection{Panoramas and Vistas for Prospecting}

The special interest of humans in art and religion started among hunter-gatherers during the Upper Palaeolithic period (Mithen, 2005 and Lewis-Williams, 2002); we can call this period the revolution of human mind. It meant a change in cognitive thinking and obviously in understanding the properties of landscape not only as locations of sites but also as surroundings offering visibility and sceneries in $3 \mathrm{D}$.

In the theory of landscape, the panorama offers a wide view from a vantage-point of $360^{\circ}$ arc over the surrounding landscape, and the vista is a view bounded by certain margins, normally by vertical or near-vertical edges. Both panoramas and vistas form direct prospects and are commanded from primary vantage-points. Natural places such as mountain tops and hilltops offering escarpments overhanging valleys or plateaus can be called natural secondary vantage-points. Artificial secondary vantage-points concern all the human-made structures which extend the vision from these areas. (Appleton, 1975). Sites of prominence are utilized at the mountain edges, such as at Tar al-Sbai, offering views over the piedmont areas(Figs. 7. and 8.). In the central area of Jebel Bishri hilltops were especially chosen for locating the previously mentioned pastoral burials and signposts.

However, to see and capture the visions of sites of prominence one needs to move by walking or while standing to rotate oneself in order to see the panoramas in $360^{\circ}$. Both the mobility of hunter-gatherers and pastoral nomads was created by the subsistence economy. This mode of life enhances visibility. The sight needs light to recognize shapes, textures, colours, movement as well as spatial dimensions like distance and depth. The eye collects information about the surrounding world, while the brain processes and interprets spatial patterns in the landscape. (Cf. Bell, 1999). The development of such qualities of observation must have especially improved during the Upper Palaeolithic and Epipalaeolithic period, when also the greater emphasis was given in constructing rock shelters at the sites offering impressive sceneries and visibility for the benefit of seasonal occupation.

\section{CONCLUSIONS}

Our identification of the early highland-lowland interaction between the mountain and the surrounding plains is emerging from archaeological data indicating seasonal cycles. The view is based on the fact that the early human groups that had been identified in the oasis of El Kowm were also traced through comparable artefact types in the mountain proper during our survey. It had become clear in our archaeological studies that related groups had not only visited the edges but also the palaeolake district in the central areas of the mountain.

Visibility must have been utilized among the hunter-gatherers and pastoralists in habitat tracking and seasonal movement in the area of Jebel Bishri. Locations in heights were chosen for site construction as well as for hunting and grazing purposes. Mountains provide several types of prominent positions for observations. Special vantage-points and look-out points were obviously utilized by the ancients at the edges where changes and movements in horizon could have been observed. The constructed landscape models using satellite data elucidate in $3 \mathrm{D}$ the chosen spaces and the possibilities for highland and lowland interaction on Jebel Bishri not only in the past but also in the present. SRTM and ASTER DEM data were utilized in creating models from Landsat and QuickBird images in 3D. The most photo-realistic models were achieved with high resolution imagery such as QuickBird. Experiments for visibility can be well carried out with such models, and the role of visibility in 
choosing sites for occupation, hunting, gathering and pastoral grazing can be better evaluated.

\section{Bibliography}

Appleton, J., 1975. The Experience of Landscape. Wiley, London.

Bar-Yosef, O., 1998. The Natufian Culture in the Levant, Threshold to the Origins of Agriculture. Evolutionary Anthropology 6(5), pp. 159-177.

Barker, G. and Bintliff, J., 1999. Geoarcaheology in Mediterranean Landscape Archaeology: Concluding Comments. In: Environmental Reconstruction in Mediterranean Landscape Archaeology, ed. by Leveau, P., Trément, F., Walsh, K. and Barker, G., The Archaeology of Mediterranean Landscapes 2, Oxbow books, Oxford, pp. 207-210.

Bell, S., 1999. Landscape: Pattern, Perception and Process. Routledge, London - New York.

Besançon, J., Copeland, L., Hours, F., Muhesen, S. and Sanlaville, P., 1981. Le Paléolithique d'El Kowm, rapport préliminaire. Paléorient, Vol. 7/1, pp. 33-55.

Braudel, F., 1972. The Mediterranean and the Mediterranean World in the Age of Philip II. Vol. I. Collins, London.

Butzer, K.W., 1982. Archaeology as human ecology. Cambridge University Press, Cambridge.

Cauvin, J., 2000. The Birth of the Gods and the Origins of Agriculture. Trans. Watkins, T. Cambridge University Press, Cambridge.

Clack, T.A.R., 2007. Memory and the Mountain: Environmental Relations of the Wachagga of Kilimanjaro and Implications for Landscape Archaeology. Cambridge Monographs in African Archaeology, 72. Series Editors: John Alexander, Laurence Smith and Insoll, T., BAR International Series 1679. Archaeopress, Oxford.

Henry, D.O., 1989. From Foraging to Agriculture: The Levant at the End of the Ice Age. University of Pennsylvania Press, Philadelphia.

Henry, D.O., 1995. Prehistoric Cultural Ecology and Evolution: Insights from Southern Jordan. Interdisciplinary Contributions to Archaeology. Plenum Press, New York.

Horden, P. and Purcell, N., 2000. The Corrupting Sea: A Study of Mediterranean History. Blackwell, Oxford.

Le Tensorer, J.M., Jagher, R., Rentzel, P., Hauck, T., IsmailMeyer, K., Pümpin, C. and Wojtczak, D., 2007. Long-term Site Formation Processes at the Natural Spring Nadaouiyeh and Hummal in the El Kowm Oasis in Central Syria. Geoarcheology 22, pp. 621-639.

Legge, A.J. and Rowly-Conwy, A., 1987. Gazelle Killing in Stone Age Syria. Scientific American 257 (2), pp. 76-83.

Lewis-Williams, D., 2002. The Mind in the Cave: Consciousness and the Origins of Art. Thames and Hudson, London.
Llobera, M., 2001. Building Past Landscape Perception with GIS: Understanding Topographic Prominence. Journal of Archaeological Science 28(9), pp. 1005-1014.

Lönnqvist, M. and Stefanakis, E., 2009. GIScience in Archaeology: Ancient Human Traces in Automated Space. In: The Manual of Geographic Information Systems, ed. by Madden, M., American Society of Photogrammetry and Remote Sensing, Bethesda, Maryland, pp. 1221-1259.

Lönnqvist, M., Stout Whiting, M., Lorentz, K., 2001. Abstract: A View over an Ancient Silicon Valley, Circular Enclosures at the Edge of Jebel Bishri, Syria, The $5^{\text {th }}$ Millennium in the Ancient Near East, Conference held in Liverpool, Nov. 2001. Forthcoming.

Lönnqvist, M. and Törmä, M., 2003. SYGIS - The Finnish Archaeological Project in Syria, The ICOMOS \& ISPRS Committee for Documentation of Cultural Heritage. In: New Perspectives to Save Cultural Heritage, CIPA 2003, XIXth International Symposium, Antalya, Turkey, ed. by Altan, O. The ISPRS International Archives of the Photogrammetry, Remote Sensing and Spatial Information Sciences, Vol. XXXIV-5/C15, pp. 609-614.

Lönnqvist, M., Törmä, M., Lönnqvist, K., Nuñez, M., Okkonen, J., Latikka, J., 2007. The Euphrates Channel Changes and Archaeology along Jebel Bishri in Syria. In: Anticipating the Future of the Cultural past, Vol. 1. Proceedings of the XXI Symposium, CIPA 2007, Athens, ed. Georgopoulos, A. The International Archives of Photogrammetry, Remote Sensing and Spatial Information Sciences, Vol. XXXVI-5/C53, pp. 465-470.

Lönnqvist, M., Törmä, M., Lönnqvist, K., Nuñez, M., 2011. Jebel Bishri in Focus: Remote sensing, archaeological surveying, mapping and GIS studies of Jebel Bishri in central Syria by the Finnish project SYGIS. British Archaeological Reports International Series 2230. Archaeopress, Oxford.

Mithen, S., 2005. The Prehistory of the Mind: A Search for the Origins of Art, Religion and Science. Phoenix, London.

More, A.M.T., Hillman, G.C. and Legge, A.J., 2000. Village on the Euphrates: From Foraging to Farming at Abu Hureyra. Oxford University Press, Oxford.

Nassauer, J.I., 1995. Culture and Changing Landscape Structure. Landscape Ecology 10 (4), pp. 229-237.

Rendell, H., 2000. Tectonic frameworks. In: Arid Zone Geomorphology: Process, Form and Change in Drylands, ed. by Thomas, David S.G. Wiley \& Sons, Chicester, pp. 13-22.

Ruiz, J.P. and Gonzalez- Bernaldez, F. 1983. Landscape perception by its traditional users: the ideal landscape of Madrid livestock raisers. Landscape planning, 6 (3-4) pp. 279-297.

Van Berg, P.-L., Vander Linden, M., Lemaitre, S., Cauwe, N. and Picalause, V., 2004. Desert-Kites of the Hemma Plateau (Hassake, Syria). Paléorient, 30 (1) pp. 89-100.

Wirth, E., 1971. Syrien: Eine geographische Landeskunde. Wissenschafliche. Länderkunden Band 4/5. Wissenschaftliche Buchgesellschaft, Darmstadt. 